\title{
Relationship Between Classification Of Heart Failure With Renal Creatinine Urea Levels
}

\author{
Eirene E.M.Gaghauna ${ }^{1}$, \\ ${ }^{1}$ STIKES Sari Mulia Banjarmasin \\ eirene_e.m.gaghauna@stikessarimulia.ac.id \\ Bagus Rahmat Santoso ${ }^{1}$ \\ ${ }^{1}$ STIKES Sari Mulia Banjarmasin \\ bagus_rahmat_santoso@stikessarimulia.ac.id \\ Irfan Sadili ${ }^{1}$ \\ ${ }^{1}$ STIKES Sari Mulia Banjarmasin \\ Irfan_sadili@ymail.com \\ Jami Hariadi Saputra ${ }^{1}$ \\ ${ }^{1}$ STIKES Sari Mulia Banjarmasin \\ Jamihs732@gmail.com
}

\begin{abstract}
Objective: The purpose of this study is to analyze the relationship between the classification of heart failure patients with renal creatinine urea levels in tulip IIC Ulin Public Hospital Banjarmasin.

Methods: This study used a cross-sectional approach. Research sampling technique used in this research is purposive sampling with the number of samples is 56 samples. Data were collected by using a checklist. Data were analyzed using Chi-Square with a significant value of $\mathrm{p}<0.05$.

Result: Results showed respondents with lower levels of urea normal were 38 respondents $(67.9 \%)$ and high urea levels as much as 18 respondents $(32.1 \%)$. Based on the results of the bivariate analysis using Chi-square test $p=0.490$ obtained because of $p>0.05(0.490>0.05)$, it can be stated there was no relationship between heart failure class with urea in Tulip IIC Ulin Public Hospital Banjarmasin. And the results showed respondents with low creatinine levels were 38 normal + respondents $(67.9 \%)$ and creatinine levels were higher by 18 respondents $(32.1 \%)$. Based on the results of the bivariate analysis using Chi-square test $\mathrm{p}=0.421$ obtained because $\mathrm{p}>0.05(0.421>0.05)$

Conclusion: Results of the analysis showed that there is no relationship between the classification of heart failure patients with renal creatinine urea levels in tulip IIC Ulin Public Hospital Banjarmasin.
\end{abstract}

Keywords: Classification of Heart Failure, Creatinine, Heart Failure, Urea

\section{INTRODUCTION}

Heart failure is a condition in which the heart fails to pump blood to meet the needs of the body's cells will be of nutrients and oxygen adequately be caused by infarction but can also be caused by a little abnormality of cardiac function caused by the condition or pressure needs a high metabolism, in addition to the heart 
failure, also caused heart attacks, hypertension or heart valve damage. It can occur suddenly or through an evolving process over several periods $(19,2,6)$.

Urea is the largest nitrogen product that is formed in the liver and excreted through the kidneys. Urea is derived from dietary and endogenous proteins that have been filtered by the glomerulus and reabsorbed in part by the tubules. In a healthy person whose diet contains a lot of protein, urea is usually located above the normal range. Low levels are usually not considered abnormal because it reflects a lack of protein in the diet or plasma volume expansion. Examination of plasma urea concentration is important and necessary in patients with kidney disease, especially to evaluate the effect of dietary protein restriction (3). Whereas creatinine is a metabolic most suitable for calculating the figures clearance and has replaced other methods such as urea clearance. Kreatinin is a decomposition product of creatine, a nitrogen-containing compound that is mainly found in the muscles. Creatine phosphorylated by the enzyme creatine phosphokinase (CPK), which is also called creatine kinase (CK), into high-energy phosphate compounds that participate in metabolic reaction that requires energy (15).

The mechanism underlying the deterioration of renal function in chronic heart failure is different than in acute heart failure. In chronic heart failure has been a reduction in renal perfusion in the long term, and often with microvascular and macrovascular disease predisposition. Although most patients with Glomular Filtration Rate (GFR) is low also at a low NYHA functional class (14).

\section{METHODS}

In this study, researchers used cross-sectional approach which causes or risk variables and effect or the case with the object of research is measured or collected simultaneously (at the same time).

The study population was all heart failure patients in the hospital room IIC tulip Ulin Banjarmasin in 2013 amounted to 350 patients.While the sample is a portion of a population of patients diagnosed with heart failure and willing to become respondents in this study are 56 patients. Sample collection techniques used in this research is purposive sampling with inclusion and exclusion criteria specified investigators. Conducted during the months of December 2014 and January 2015. In the space of tulips IIC Hospital Ulin Banjarmasin.

Sources of data in this study is a secondary data source with observation technique using a checklist sheet. Secondary data is data obtained by researchers indirectly, to obtain the necessary data are obtained from laboratory results from the data entry status respondents were then calculated from the ratio of urea creatinine levels change with the classification of heart failure patients. The data processing is done with the help of a computer through the steps that, Editing (checking), Coding (coding), data entry (entering data), and 
Cleaning (data cleansing). The data collected were processed and analyzed with univariate and bivariate analysis.

\section{RESULT}

1. General overview of the study site

RSUD Ulin Banjarmasin is home to South Kalimantan provincial government that stands in the area of the land area of $63.920 \mathrm{~m} 2$ with a building area of $47.619 \mathrm{~m} 2$. The hospital is located in the city center of Banjarmasin which is a teaching hospital type A. The hospital has territorial limits as follows: north bordering the road Ahmad Yani, south by the Veteran. East land border with the Simpang Ulin and the west land border with Veterans complex.

Ulin General Hospital also has passed the accreditation of 16 services, even for Space Care Aster own certificate of ISO 9002. The hospital is a referral center for the region of South Kalimantan, Central Kalimantan and East Kalimantan.

2. characteristics of respondents

Characteristics of respondents obtained include gender and age.

a. Gender Respondents

Characteristics of respondents by sex of patients with heart failure in the following table:

Table 1 Distribution of respondents by gender

\begin{tabular}{|c|c|c|}
\hline Category & Frequency & Percentage \\
\hline Man & 30 & $53.6 \%$ \\
\hline woman & 26 & $46.4 \%$ \\
\hline amount & 56 & 100 \\
\hline
\end{tabular}

Based on Table 4.1 it can be seen that out of 56 respondents, respondents gender male of 30 respondents $53.6 \%$ ) and female respondents were 26 respondents (46.4\%). Most of the respondents are the males.

b. Respondents age

Characteristics of respondents by age of patients with heart failure in the following table:

Table 2 Distribution of Respondents by Age

\begin{tabular}{ccc}
\hline Age & Frequency & Percentage \\
\hline 21-30 Year & 1 & $1.8 \%$ \\
31-40 Year & 3 & $5.3 \%$ \\
41-50 Years & 8 & $14.3 \%$ \\
$>51$ Year & 44 & $78.6 \%$ \\
\hline amount & 56 & 100
\end{tabular}

Source: Primary Data, 2015

Table 4.2 based assessment of individual characteristics of respondents categorized by age 4 levels were age 21-30 years as one respondent (1.8\%), $31-40$ years of as much as 3 respondents (5.3\%), $41-50$ years of as much as 8 respondents $(14.3 \%)$ and $>51$ years were 44 respondents $(78.6 \%)$. If seen in Table 4.2 can be seen that out of 56 respondents most heart failure patients $>50$ years were 44 respondents $(78.6 \%)$

3. Univariate analysis

a. Heart Failure Class

Class heart failure is classified into class I, class II, class III and class IV. Class frequency distribution of heart failure at the Hospital of Ulin Banjarmasin Tulip IIC can be seen in the following 
table:

Table 3 Distribution of Heart Failure Class

\begin{tabular}{lcc}
\hline \multicolumn{1}{c}{ Category } & Frequency & Percentage \\
\hline class I & 22 & $39.3 \%$ \\
class II & 24 & $42.9 \%$ \\
class III & 7 & $12.5 \%$ \\
class IV & 3 & $5.4 \%$ \\
\hline \multicolumn{1}{c}{ amount } & 56 & 100
\end{tabular}

Source: Primary Data, 2014

Based on Table 4.3 it can be seen that out of 56 respondents, respondents were class II heart failure as much as 24 respondents $(42.9 \%)$, heart failure class I as much as 22 respondents (39.3\%), class III heart failure by 7 respondents $(12,5 \%)$ and class IV heart failure as much as 3 respondents $(5.4 \%)$.

b. levels of urea

Research urea levels are grouped into low, normal, and high. The frequency distribution urea levels in heart failure patients in hospitals IIC Tulip Lounge Ulin Banjarmasin can be seen in the following table:

table 4 Frequency Distribution of Urea Levels

\begin{tabular}{|c|c|c|}
\hline Category & Frequency & Percentage \\
\hline Low & 0 & $35 \%$ \\
\hline Normal & 38 & $50 \%$ \\
\hline High & 18 & $15 \%$ \\
\hline amount & 56 & 100 \\
\hline
\end{tabular}

Based on Table 4.4 it can be seen that out of 56 respondents, there are no respondents with lower urea levels $(0 \%)$, normal urea levels were 38 respondents (67.9\%) and high urea levels as much as 18 respondents $(32.1 \%)$.

c. Creatinine levels

Research creatinine levels are grouped into low, normal, and high. The frequency distribution creatinine levels in heart failure patients in hospitals IIC Tulip Lounge Ulin Banjarmasin can be seen in the following table:

table 5 Frequency distribution Creatinine Levels

\begin{tabular}{|c|c|c|}
\hline Category & Frequency & Percentage \\
\hline Low & 2 & $3.6 \%$ \\
\hline Normal & 36 & $64.3 \%$ \\
\hline High & 18 & $32.1 \%$ \\
\hline amount & 56 & 100 \\
\hline
\end{tabular}

Based on Table 4.5 it can be seen that out of 56 respondents, respondents with low creatinine levels as much as 2 respondents (3.6\%), normal creatinine levels as much as 36 respondents $(64.3 \%)$ and high creatinine levels as much as 18 respondents $(32.1 \%)$,

d. Bivariate analysis

The bivariate analysis was conducted to see the relationship between independent variables and the dependent variable using the Kolmogorov-Smirnov test. The research found no correlation Heart Failure Class with urea creatinine in patients with heart failure in the Tulip room IIC Hospital Ulin Banjarmasin, this can be seen in the cross-tabulations as follows:

Table 6 Cross-tabulation of the Heart Failure Class Levels urea

\begin{tabular}{cccccc}
\hline Heart & \multicolumn{5}{c}{ levels of urea } \\
\cline { 2 - 5 } $\begin{array}{c}\text { Failure } \\
\text { Class }\end{array}$ & $\begin{array}{c}\text { Low }+ \\
\text { Normal }\end{array}$ & $\%$ & High & $\%$ & \\
\hline class I & 14 & 36.8 & 8 & 44.4 & 0,296 \\
class II & 18 & 47.4 & 6 & 33.3 & \\
class III & 5 & 13.2 & 2 & 11.1 & \\
class IV & 1 & 2.6 & 2 & 11.1 & \\
\hline Total & 38 & 67.9 & 18 & 32.1 & \\
\hline
\end{tabular}

Based on table 4.6 of the respondents 
were class II heart failure as much as 24 respondents $(42.9 \%)$, heart failure class I as much as 22 respondents (39.3\%), class III heart failure by 7 respondents $(12.5 \%)$ and heart failure IV class as much as 3 respondents (5.4\%). Respondents with lower + normal urea levels were 38 respondents (67.9\%) and high urea levels as much as 18 respondents (32.1\%). Based on the results of the bivariate analysis using the Kolmogorov-Smirnov test obtained by value $p=0.490$ for $p>0.05(0.490>0.05)$, it can be stated there is no relationship between class heart failure with urea at Tulip Lounge IIC Hospital Ulin Banjarmasin.

Table 7 Class A cross-tabulation of Heart Failure with Creatinine Levels in Patients with Heart Failure

\begin{tabular}{|c|c|c|c|c|c|}
\hline \multirow{2}{*}{$\begin{array}{l}\text { Heart } \\
\text { Failure } \\
\text { Class }\end{array}$} & \multicolumn{4}{|c|}{ Creatinine levels } & \multirow[b]{2}{*}{$p$} \\
\hline & $\begin{array}{c}\text { Low }+ \\
\text { Normal } \\
\end{array}$ & $\%$ & High & $\%$ & \\
\hline class I & 16 & 42.1 & 6 & 33.3 & 0,296 \\
\hline class II & 17 & 44.7 & 7 & 38.9 & \\
\hline class III & 4 & 10.5 & 3 & 16.7 & \\
\hline class IV & 1 & 2.6 & 2 & 11.1 & \\
\hline Total & 38 & 67.9 & 18 & 32.1 & \\
\hline
\end{tabular}

Based on table 4.6 of the respondents heart failure class $I$ as much as 22 respondents $(39.3 \%)$, heart failure class II as many as 24 respondents $(42.9 \%)$, class III heart failure by 7 respondents $(12.5 \%)$ and heart failure IV class as much as 3 respondents (5.4\%). Respondents with lower + normal creatinine levels were 38 respondents $(67.9 \%)$ and high creatinine levels as much as 18 respondents (32.1\%). Based on the results of the bivariate analysis using the Kolmogorov-Smirnov test obtained by value $\mathrm{p}=0.421$ for $\mathrm{p}>0.05(0.421>0.05)$, it can be stated there is no relationship between the classes of heart failure with creatinine levels at the Tulip Lounge IIC Hospital Ulin Banjarmasin.

\section{DISCUSSION}

1. Classification of Heart Failure Patients

Class heart failure based on symptoms associated with functional capacity that was developed by the New York Heart Association (NYHA) (16). Quoted from Dumitru, 2012 and Salters, et al 2010 split NYHA classification of heart failure according to the signs and symptoms caused, classification is divided into four classes.

Heart failure is a condition in which the heart fails to pump blood to meet the needs of the body's cells will be of nutrients and oxygen adequately be caused by infarction but can also be caused by a little abnormality of cardiac function caused by the condition or pressure needs a high metabolism, in addition to the heart failure, also caused heart attacks, hypertension or heart valve damage. It can occur suddenly or through an evolving process over several periods $(19,2,6)$.

Based on the analysis in the research note that most respondents classified heart failure in heart failure class II. In this study, sheet signed an informed consent of patients or families, and sheet Checklist sees the contents of laboratory results in the patient's 
status with permission of the patient or family. As well as the class division determined by the headspace IIC Tulip Care Hospital Ulin Banjarmasin, wherein in determining heart failure class researchers observed the activity of the respondent.

This study found that patients treated in hospitals IIC Tulip Lounge Ulin mostly come with functional class II symptoms patients experience few limitations. This is similar to the research conducted by Patricia et al, 2012 in which the patients who come for treatment to the Polyclinic Heart mostly come with functional class II or approximately $43 \%$. This is due to heart failure class II, most of the hospitalization.

\section{Levels of urea Kidney}

Based on the survey results revealed that out of 56 respondents, most respondents to the urea normal, based on these results this study, researchers urea creatinine is not only affected by kidney disease, but also by the input of protein in the diet, the catabolism of tissue and wound RBC and steroids ( 17). According to Price and Lorraine (1998) kidneys remove waste metabolic functions (such as urea, creatinine and uric acid), a foreign chemical substance and produces renin, the active form of vitamin D as well as erythropoietin, but this function will decline even stop when the kidneys are unable to do so.

Patients with normal urea levels due to consumption of protein consumed by patients who later became a product of nitrogen does not exceed the ability of glomerular filtration and partly reabsorbed by the tubules in the kidney. The medium according to Effendi, 2006 stated that urea is the largest nitrogen product that is formed in the liver and excreted through the kidneys. On the decline in renal function, increased levels of BUN BUN so that measurements can give clues about the state of the kidney. Examination of plasma urea concentration is important and necessary in patients with kidney disease, especially to evaluate the effect of dietary protein restriction. Urea concentration is generally expressed as the nitrogen content of the molecule, ie blood urea nitrogen (blood urea nitrogen, BUN) (3.13).

\section{Kidney Creatinine Levels}

Based on the survey results revealed that out of 56 respondents, most respondents with normal creatinine levels. This is in accordance with the Sacher \& McPherson, 2004 states that every person, the amount of creatinine produced from creatine turnover tends to be constant. Total generated and do not vary significantly excreted in urine volume. Same thing with research conducted by Nugrahani 2007 where the results of research conducted on the number of respondents including the elderly are only $9.83 \%$ so that the majority of patients with normal creatinine values. Results of the study were mostly heart failure patients aged over 51 years is $78.6 \%$ where the age is one factor that can affect the value of creatinine in room 
IIC Tulip Hospital Ulin Banjarmasin.

4. Heart failure class relationships with urea The results of data analysis using statistical test of Kolmogorov-Smirnov test, two heart failure class variable with the urea obtained significant value $\mathrm{p}=0.490>(0.05)$. It can be concluded that there is no relationship between heart failure class with urea levels in patients with heart failure hospital room IIC tulip Ulin Banjarmasin. This is not in accordance with the theory put forward by Ronco C, 2008 stating that the majority of patients with Glomular Filtration Rate (GFR) is low also at a low NYHA functional class. The absence of class relationships with urea due to urea formed from the breakdown of proteins, especially those from the food by Price, 2005.

The absence of heart failure class relationship with the urea creatinine approach to research conducted Patricia et al, 2012 in the BLU / Dr. PROF. DR. RD Kandou Manado of 30 respondents, There was no relationship NYHA class with an ejection fraction of this can occur because of an increase and decrease in ejection fraction unstable and influenced by the delivery and use of optimal drug dose. Another factor that can affect NYHA class is age, duration of heart failure, other diseases such as chronic renal failure, angina pectoris, use of diuretics, jugular venous pressure, lower extremity edema, and pulmonary congestion.

urea precisely fluctuations beyond normal levels as a result of patients do not diet in accordance with the condition (5.1),Because the kidneys excrete the end result of metabolism, particularly the final outcome of the metabolism of proteins, is urea (8) so that the implications of nursing implementing interventions for health education on the prevention of an increase in urea levels in patients with heart failure, such as diet high in protein, prevents dehydration, prevent catabolism which increases as the infection or fever, according to the theory Tjokronegoro 2001 because apart due to renal dysfunction can also be caused by dehydration, high protein intake, and increased catabolism such as infection or fever. This is done so that no complications of renal failure resulting in hemodialysis patients with heart failure.

5. Heart failure class relationship with creatinine levels

The results of data analysis using statistical test of Kolmogorov-Smirnov test, of two class variables of heart failure with creatinine levels obtained significant value $\mathrm{p}=0.504>(0.05)$. It can be concluded that there is no relationship between the classes of heart failure with creatinine levels of heart failure patients in the hospital room IIC tulip Ulin Banjarmasin. This is not in accordance with the theory put forward by Ronco C, 2008 stating that the majority of patients with Glomular Filtration Rate (GFR) is low also at a low NYHA functional class. The absence of class relationships with creatinine levels caused by Smeltzer and Bare, 2002 creatinine is determined by the amount of muscle mass (protein catabolism rate), in 
addition to how our body's metabolic activity, for example, increases when we are sick (hot / infection). This is in line with a study done by Nabella 2011 stating that there is a relationship between the intake of protein to creatinine levels. So that the protein diet can cause heart failure patients creatinine levels at the Tulip Lounge IIC Hospital Ulin Banjarmasin mostly normal.

According to Gibsons (2005) in research Nugrahani 2007 of several factors that influence blood creatinine, creatine, and creatinine daily intake of meat or supplements, infection, fever, trauma can increase creatinine excretion. In addition to the high creatinine ratio can also be found in patients with reduced muscle mass, impaired renal function accompanied by a diet high in protein, tissue destruction, and myopathy associated with thyrotoxicosis or syndromes (15).

But often the urea creatinine precisely fluctuations beyond normal levels as a result of patients do not diet in accordance with the condition (5.1). So that heart failure patient who have elevated creatinine levels should carry out a protein diet, besides the case in patients who require treatment, fluid restriction (1,52I / day) and salt restriction are recommended in patients. Short-term bed rest can help improve symptoms by reducing the metabolism and improve renal perfusion (4).

\section{CONCLUSION}

Based on the analysis and discussion which has been described previously about the relationship classification of heart failure patients with renal creatinine urea levels in the Room tulip Hospital Ulin Banjarmasin IIC was concluded as follows:

1. Classification of heart failure patients in the hospital room IIC tulip Ulin Banjarmasin mostly in the category of class II, namely $42.9 \%$.

2. Urea levels of heart failure patients in the hospital room IIC tulip Ulin Banjarmasin mostly within the normal ranges, namely $67.9 \%$.

3. Creatinine levels of heart failure patients in the hospital room IIC tulip Ulin Banjarmasin mostly within the normal ranges, namely $64.3 \%$.

4. There is no relationship between heart failure class with urea levels in patients with heart failure hospital room IIC Tulip Ulin Banjarmasin

5. There is no relationship between the classes of heart failure with creatinine levels of heart failure patients in the hospital room IIC Tulip Ulin Banjarmasin.

\section{REFERENCES}

[1].Curley MAQ and Maloney-Harmon PA. Critical Care Nursing of Infants and Children. 2nd edition, WB Saunders Co., Philadelphia.2001.

[2].Dumitru, I. Heart Failure. Available from:http://emedicine.medscape.com/ar ticle/163062-overview\#showall. 2012

[3].Effendi I, Markum H. Investigations on Kidney Disease. In: Sudoyo AW, editor. Textbook of Medicine. 4th ed. Jakarta: The Medicine Faculty of Medicine; 2006. p. 506-7.

[4].CR Gibbs, Jackson G, Lip GYH. ABC 
of heart failure: non-drug management. BMJ 2000; 320: 366-9.

[5].CM Hudak and Gallo BM. Critical Care, a holistic approach.. Volume II, VI edition, EGC, Jakarta. 1996

[6].Krum, H., \& Abraham, WT. Heart failure. The Lancet, 373 (9667), 941-955. 2009

[7]. Nabella, Masceny. Protein intake relationships with urea and creatinine levels in Bodybuilder. Available from: http://eprints.undip.ac.id/35913/1/418_ Hascemy_Nabella_G2C007036.pdf [Acceased 11 November 2014]. 2011

[8].Naga, SS Complete Handbook of Medicine. Jogjakarta: DIVA Press. 2013

[9].Nugrahani, Azizah. , Against Protein Intake Levels relationship Urea Nitrogen, Creatinine, Albumin Blood And Chronic Kidney Disease Patients Undergoing Hemodialysis at Dr. Yang Dr. Sardjito https://muslimpinang.files.wordpress.co m/2010/10/azizah-nugraheni.pdf

[Acceased 19 January 2015]. 2007

[10].Patricia. NYHA Class Relationship With Ejection Fraction in Patients with Chronic Heart Failure In Blu / Dr. Prof. Dr. RD Kandou Manado. Available from:http://ejournal.unsrat.ac.id/index.p hp/eclinic/article/view/3266/2810 [Acceased 19 January 2015]. 2012

[11].Price, SA, pathophysiology, clinical concepts diseases, EGC, Jakarta. 2005

[12].Price SA and Lorraine CW. Concept Clinical Pathophysiology Disease Processes, (translation), EGC, Jakarta. 1998.

[13]. Riswanto. Blood urea. Available from: http://labkesehatan.blogspot.com/2010/ 03/ureum-darah-serum.html. [Acceased 13 October 2014]. 2010

[14]. Ronco C, A House A, Haapio M. Cardiorenal and renocardic syndromes: the need for a comprehensive, classification and consensus. Nature Publishing Group, 2008.

[15].Sacher, RA, \& McPherson RA, Overview Hasin Clinical Laboratory Tests. 11. Issue Jakarta: EGC. 2004

[16]. Siswanto BB, Dharma S, Juzan DA, Sukmawan R. Guidelines for
Management of Cardiovascular Diseases in Indonesia. Jakarta: Cardiovascular Specialist Doctors Association of Indonesia. 2009: 267268.

[17].Smeltzer, SC, and Bare, BG, textbook of medical surgical nursing 3rd Edition, Volume 2, EGC, Jakarta. 2002

[18].Tjokronegoro, Arjatmo \& Main Hendra. Textbook of Internal Medicine Volume II. third edition. Jakarta: New Style. 2001

[19].Udjianti, Frying Pan June. Cardiovascular Nursing. Jakarta: Salemba. 2010 